Int. J. Plant Sci. 174(3):269-277. 2013.

(c) 2013 by The University of Chicago. All rights reserved.

1058-5893/2013/17403-0002\$15.00 DOI: $10.1086 / 668247$

\title{
A PUTATIVE ZYGOMYCETOUS FUNGUS WITH MANTLED ZYGOSPORANGIA AND APPOSED GAMETANGIA FROM THE LOWER COAL MEASURES (CARBONIFEROUS) OF GREAT BRITAIN
}

\author{
Michael Krings, ${ }^{1, *} \uparrow$ James F. White Jr., $\neq$ Nora Dotzler, ${ }^{*}$ and Carla J. Harper $\dagger$ \\ *Department für Geo- und Umweltwissenschaften, Paläontologie und Geobiologie, Ludwig-Maximilians-Universität, Richard-Wagner-Straße 10, \\ 80333 Munich, Germany, and Bayerische Staatssammlung für Paläontologie und Geologie, Richard-Wagner-Straße 10, 80333 Munich, \\ Germany; †Department of Ecology and Evolutionary Biology, University of Kansas, Lawrence, Kansas 66045, U.S.A., and Natural \\ History Museum and Biodiversity Research Institute, University of Kansas, Lawrence, Kansas 66045, U.S.A.; and ¥Department \\ of Plant Biology and Pathology, Rutgers University, New Brunswick, New Jersey 08901, U.S.A.
}

Several specimens of a new fungal reproductive unit, Halifaxia taylorii nov. gen. et spec., occur within the tracheids of a structurally preserved fern axis from the Lower Pennsylvanian of Great Britain. The reproductive units, which appear to be lateral outgrowths of tubular hyphae, consist of a mantled sphere $(80-90 \mu \mathrm{m}$ in diameter) borne terminally on an inflated subtending structure, which may also be mantled. A smaller element clasps the proximal portion of the subtending structure; one arm of this element extends further up along and appears to eventually fuse laterally with the subtending structure. The reproductive units are interpreted as zygosporangium-apposed gametangia complexes of a zygomycetous fungus. Although several structural features of $H$. taylorii resemble features seen in the zygosporangium-gametangia complexes of certain modern zygomycetes, the precise systematic affinities of the fossils remain unresolved. Nevertheless, the discovery is important because it provides new information on the morphology and evolutionary history of the zygomycetous fungi, which are poorly resolved on the basis of fossils.

Keywords: Endogonaceae, fossil fungi, gametangial fusion, Lower Pennsylvanian, Mortierellaceae, zygosporangiogenesis.

\section{Introduction}

The zygomycetous fungi (formerly Zygomycota) are an ecologically heterogeneous, paraphyletic or polyphyletic assemblage of predominantly terrestrial organisms (White et al. 2006; Liu et al. 2009; Liu and Voigt 2010). They reproduce asexually via nonmotile endospores formed in sporangia, sporangiola, or merosporangia or by the formation of chlamydospores, arthrospores, and yeast cells, and they reproduce sexually (where documented) by the formation of zygospores following gametangial fusion or azygospores without prior gametangial conjugation (Benjamin 1979; Benny et al. 2001). Most zygomycetous fungi thrive as saprotrophs, others as parasites of plants, animals, and other fungi (White et al. 2006; Richardson 2009); still others enter into mutualistic associations (mycorrhizae) with plants (Fassi et al. 1969; Walker 1985).

Molecular clock estimates suggest that the first zygomycetous fungi occurred on Earth during the Precambrian, $~ 1.2-1.4 \mathrm{Ga}$ ago (Heckman et al. 2001; Blair 2009); more conservative estimates place the divergence at $\sim 800 \mathrm{Ma}$ (Berbee and Taylor 2001). If these estimates are accurate, zygomycetous fungi might have been important elements in ancient terrestrial

${ }^{1}$ Author for correspondence; e-mail: m.krings@lrz.uni-muenchen.de.

Manuscript received March 2012; revised manuscript received June 2012. ecosystems. Nevertheless, documented fossil evidence is meager. The scarcity of reports on fossil zygomycetes appears to be related to the nature of the fossil record of fungi that typically results in the preservation of isolated parts or stages of the life cycle. Most structures formed during the zygomycetous life cycle are nondiagnostic at the level of resolution available with light microscopy. Mature zygosporangia/zygospores with attached gametangia and suspensors (see Benjamin 1979) appear to be the only component of the life cycle that can be used to positively identify a fossil zygomycete (Krings and Taylor 2012a).

The oldest fossil evidence of zygomycetous fungi occurs in the form of reproductive units interpreted as zygosporangia with apposed gametangia from the Lower Pennsylvanian (Carboniferous) of Great Britain (Krings and Taylor 2012a, 2012b). Another Pennsylvanian fossil believed to represent a zygomycete is Protoascon missouriensis LR Batra et al. (Batra et al. 1964; Baxter 1975), a structure consisting of a bulb-like suspensor with appendages arising in a whorl from one end and forming a basket-like structure around an ornamented azygo- or zygosporangium (Taylor et al. 2005). Perhaps the most convincing fossil zygomycete to date is Jimwhitea circumtecta M Krings et TN Taylor, a zygosporangium-apposed gametangia complex from the Triassic of Antarctica that is strikingly similar to the zygosporangium-gametangia complexes seen in certain extant species of Endogone Link: Fr. (Krings et al. 2012). Other fossils of putatively zygomycetous sexual reproductive structures from the Triassic of Antarctica include several 
intact sporocarps containing spores, in part sheathed by a hyphal mantle, also suggested as belonging to the Endogonales (White and Taylor 1989, 1991). Although these fossils indicate that zygomycetous fungi have existed at least since the Carboniferous, many additional specimens are needed in order to accurately assess the fossil record, evolutionary history, and role(s) in paleoecology of this phylogenetically difficult group of fungi.

This article describes Halifaxia taylorii nov. gen. et spec., a newly discovered fungal reproductive unit that occurs within the tracheids of a permineralized fern axis from the Lower Coal Measures (Lower Pennsylvanian) of Great Britain. The fossils are interpreted as mantled zygosporangia subtended by a large gametangium. Attached laterally to the subtending structure is a small gametangium. Although the fossils are somewhat reminiscent of the zygosporangiumapposed gametangia complexes in certain modern Endogonaceae (Endogonales), their precise systematic affinities cannot be determined. Nevertheless, the discovery is important because it provides new information on the evolutionary history of the zygomycetous fungi.

\section{Material and Methods}

The fossils described in this study come from a single thin section that was prepared from a coal ball collected in the Lower Coal Measures of Great Britain. The coal ball comes from the Halifax Hard Seam at Halifax (Yorkshire), which is Westphalian A or Langsettian (Bashkirian/Lower Pennsylvanian) in age (Galtier 1997). The section was prepared according to standard procedures, in which a piece of the coal ball was cemented to a glass slide and subsequently ground with abrasive until it was thin enough to be examined with transmitted light. The slide is part of the Williamson collection that is housed in the Natural History Museum in London; the slide has accession number 1929 (drawer 54). The fossils were analyzed using normal transmitted light microscopy equipment. Digital images were captured with a Leica DFC-480 camera and processed in Adobe Photoshop.

\section{Systematic Paleomycology \\ Zygomycetous Fungi \\ Subphylum - Incertae sedis \\ Genus_-Halifaxia M Krings, JF White, \\ Dotzler et CJ Harper nov. gen. \\ MycoBank MB 564544 \\ Type-Halifaxia taylorii M Krings, JF White, Dotzler et CJ Harper (This Article)}

Generic diagnosis. Fossil zygomycetous sexual reproductive structure (zygosporangium-gametangia complex), produced singly (not in unstructured masses or sporocarps); zygosporangium with hyphal mantle; gametangia apposed, differentiated (macrogametangium [see "Remarks" for specification on usage of term] larger than microgametangium); microgametangial branch may arise from distinctive parental element; microgametangium fusing laterally with macrogametangium; zygosporangium arising from tip of macrogametangium.

Etymology. The generic name Halifaxia indicates that the coal ball containing the fungus has been collected from the Halifax Hard Seam at Halifax in Yorkshire, Great Britain.

\section{Species_-Halifaxia taylorii M Krings, JF White, Dotzler et CJ Harper nov. spec. (Figs. 1A-1D, 1F-1L, 2)}

\section{MycoBank MB 564545}

Diagnosis. Zygosporangium spherical, 80-90 $\mu \mathrm{m}$ in diameter (including mantle); mantle up to $10 \mu \mathrm{m}$ thick, composed of irregularly swollen, interlaced, aseptate hyphae and peripheral tubular hyphae extending along circumference of zygosporangium; gametangia arising from tubular running hyphae; macrogametangium inflated, elongate, sac-like or conical, usually (but not always) sheathed by loosely interwoven hyphae; microgametangium considerably smaller than macrogametangium, borne on stout branch (microgametangial branch) extending up along outer surface of macrogametangium; microgametangial branch may be subtended by irregularly lobed or branched aseptate element clasping around proximal portion of macrogametangium; microgametangial branch and its subtending element not sheathed by hyphae.

Holotype (bic designatus). Specimen illustrated in figure $1 F$ (details in figs. $1 J-1 L, 2 A, 2 B$ ).

Repository. Williamson collection slide 1929 (in drawer 54), Natural History Museum, London.

Etymology. The epithet is proposed in honor of Thomas N. Taylor, University of Kansas, Lawrence, Kansas, for his preeminent contributions to our understanding of the biodiversity of fossil fungi and the biological roles of fungi in paleoecosystems.

Stratigraphic occurrence. Halifax Hard Seam at Halifax, Yorkshire, Great Britain.

Age. Westphalian A or Langsettian (Bashkirian, Lower Pennsylvanian, Carboniferous), according to Galtier (1997).

Description. Halifaxia taylorii occurs in the xylem of a structurally preserved (permineralized) pinna axis $(\sim 2 \mathrm{~mm}$ wide) of a fern of unknown affinity that appears in longitudinal section (fig. 1A); the assemblage of fungal remains consists of variously sized hyphae and five reproductive units, four of which occur in linear arrangement within one tracheid (fig. $1 A$ [bracketed area], $1 B$ ), while the fifth is located at some distance from the others in an adjacent tracheid (fig. $1 A$ [arrow], $1 F)$. Similar reproductive units have not been detected in any other plant tissue preserved in this or other thin sections from the British Coal Measures kept in the Williamson or any other collection, nor have they been found in the matrix of these coal ball sections. However, on the outer surface of the fern axis containing $H$. taylorii occurs a cluster of small (45-80 $\mu \mathrm{m}$ in diameter) spheres surrounded by a hyphal investment (fig. $1 E$ ) that might represent partially degraded reproductive units of $H$. taylorii but could as well belong to some other fungus.

Tubular running hyphae in the tracheids are thin walled, up to $6 \mu \mathrm{m}$ wide, and aseptate; they typically extend along 
the long axis of the host cells (fig. $1 B, 1 D, 1 G, 1 H$ ). Branching is infrequent. If branching occurs, the hyphal branch may be as wide as the parental hypha and also extend along the long axis of the tracheids or slightly wider and directed more or less perpendicularly to the parental hypha. Perpendicularly oriented branch hyphae may be aseptate or contain irregularly spaced right-angled septa (fig. $1 C$, arrows) and usually produce second-order branches $2-2.5(-4) \mu \mathrm{m}$ wide (fig. $1 B$, $1 C)$. Although it is likely that the reproductive units were produced on lateral branches of the running hyphae (or as lateral outgrowths of the running hyphae), direct evidence of a physical connection has not been found, with one possible exception (figs. $1 G$ [bracketed area], $2 G$ [arrow]).

Reproductive units occur singly, albeit four of the individuals are located in close proximity to one another within one host cell. They consist of a sphere (fig. 1J) subtended by an inflated structure, informally termed "subtending structure" in this study (fig. 1J, ss), which is present in four of the specimens. An irregularly shaped element, termed "smaller element" in this report (fig. $1 \mathrm{~J}$, se), is found attached to the proximal portion of the subtending structure in three of the specimens. The sphere is $85-90 \mu \mathrm{m}$ in diameter and composed of a central cavity, $\sim 70 \mu \mathrm{m}$ in diameter, surrounded by a hyphal investment or mantle. The investment/mantle is 7-10 $\mu \mathrm{m}$ thick and constructed of a system of interlaced hyphae that are irregularly swollen and $1-4(-5) \mu \mathrm{m}$ wide (figs. $1 H, 1 I, 2 D-2 F)$. Tubular hyphae (up to $2 \mu \mathrm{m}$ wide) extending around the circumference of the sphere occur in the periphery (fig. 2D, 2E). All hyphae are relatively thin walled; septa have not been observed, but hyphal constrictions frequently occur (fig. 2E). In several instances, hyphae extend from the investment into the surrounding matrix (figs. $1 \mathrm{H}$ [arrows], $2 F$ [arrow]).

The subtending structure (figs. $1 F, 1 G, 1 I, 1 J$ [ss] $2 A, 2 B$, $2 D, 2 G-2 I)$ is elongate, sac like, or chiefly conical, up to $60 \mu \mathrm{m}$ long and $30 \mu \mathrm{m}$ wide, and in most (but not all; fig. $2 A, 2 B$ ) specimens sheathed by a one-layered meshwork of loosely interwoven hyphae (fig. $2 \mathrm{G}, 2 \mathrm{H}$ ). The hyphae sheathing the subtending structure are similar in size and morphology to the hyphae investing the sphere. The proximal portion of the subtending structure is tapering; one specimen (fig. $2 A$ ) indicates that the subtending structure arises from a tubular hypha (phss) and may produce branches (br) proximally.

Physically connected to the subtending structure in three of the reproductive units is a smaller element, which lacks a hyphal investment (figs. $1 J$ [se]- $1 L, 2 B, 2 D, 2 H$ [arrow], $2 I$ [arrow]). The three-dimensional configuration of and relationship between the subtending structure and this element is best recognizable from the specimen illustrated in different magnifications and focal planes in figures $1 J-1 L, 2 A$, and $2 B$. The smaller element develops from a tubular hypha or hyphal branch (fig. $1 J, 1 \mathrm{~K}$ [phse]) by irregular inflation, lobation, and the formation of branches (fig. $1 K$, br). The element, which apparently is entirely aseptate, clasps the proximal portion of the subtending structure (figs. $1 L, 2 B$ ) and then produces one stout branch (up to $12 \mu \mathrm{m}$ wide) that extends further up along the outer surface of the subtending structure. The tip of this branch appears to fuse laterally with the subtending structure (fig. 2D, 2I). A transverse septum separates the distal portion of the branch from the rest (fig. 2B, black arrow). In the other two reproductive units evidencing the presence of the smaller element (1: fig. $2 D$, $2 \mathrm{H}$; 2: figs. $1 \mathrm{I}, 2 \mathrm{I}$ ), only the tubular branch extending along the subtending structure appears in the thin section. One of these specimens also documents the septum separating the distal portion of the branch from the rest (fig. $2 D$, arrow).

An interesting fossil (fig. $2 B$, top) co-occurring with one of the $H$. taylorii reproductive units consists of a distal spheroid $(\sim 16 \mu \mathrm{m}$ in diameter) and a cylindrical element, which is $40 \mu \mathrm{m}$ long, up to $18 \mu \mathrm{m}$ wide, and characterized by a transverse wall separating the distal third from the rest (fig. $2 C_{2}$, white arrow). A second distinctive transverse wall is visible at the tip of the cylindrical element (fig. $2 B, 2 C_{2}$ [black arrow]). Behind the cylindrical element occurs a thin-walled, slightly inflated structure $(\sim 20 \mu \mathrm{m}$ wide $)$ that appears to be tapering proximally (fig. $2 B$, white arrows). It remains unclear whether the spheroid is subtended by the cylindrical element or by the slightly inflated structure. Several tubular hyphae (2.5-4 $\mu \mathrm{m}$ wide) approach the complex from the outside (fig. $2 C_{1}$, arrow).

Remarks. A septum demarcating the macrogametangium is not recognizable in the fossils. In the diagnoses, we have used the term "macrogametangium" for the entire structure subtending the zygosporangium, notwithstanding that this structure might represent the macrogametangium, or the macrogametangium and macrosuspensor (see "Discussion"). We assign the fossils to the zygomycetous fungi on the basis of morphological features of what are interpreted as zygosporangium-gametangia complexes. It is currently impossible to further delimit the affinities of the fossils within the zygomycetous fungi; therefore, we do not resolve the ranks of subphylum and below.

\section{Discussion}

The occurrence of well-preserved fungi and fungus-like organisms in coal balls from the Lower Coal Measures of Great Britain has been known for more than $130 \mathrm{yr}$ (Cash and Hick 1879; Williamson 1880, 1881, 1883). However, these fossils are just now beginning to be more fully appreciated as a source of new information on fungal diversity, biology, and role(s) in ecosystems in the Carboniferous (Krings et al. 2010a, 2011a, 2011b; Strullu-Derrien et al. 2011). Halifaxia taylorii represents an excellent example of the high preservational quality of some of the fungal fossils from the British coal balls. Although the specimens depict only one stage in the life history of this fungus, the complement of structural features exhibited is sufficient enough to be used to compare the fossils with modern fungi and advance hypotheses on the systematic affinities of the fossils.

\section{Assignment to the Zygomycetous Fungi}

The fungal reproductive unit $H$. taylorii consists of a sphere surrounded by a hyphal investment (fig. $2 D-2 F$ ) and two prominent and elaborate associated structures (informally termed "subtending structure" and "smaller element" in the description) that are interconnected (figs. $1 J-1 L, 2 A, 2 B$, $2 G-2 I$ ). Hyphal investments (or mantles) similar to that seen in the fossils are known to occur on the spores of several ex- 


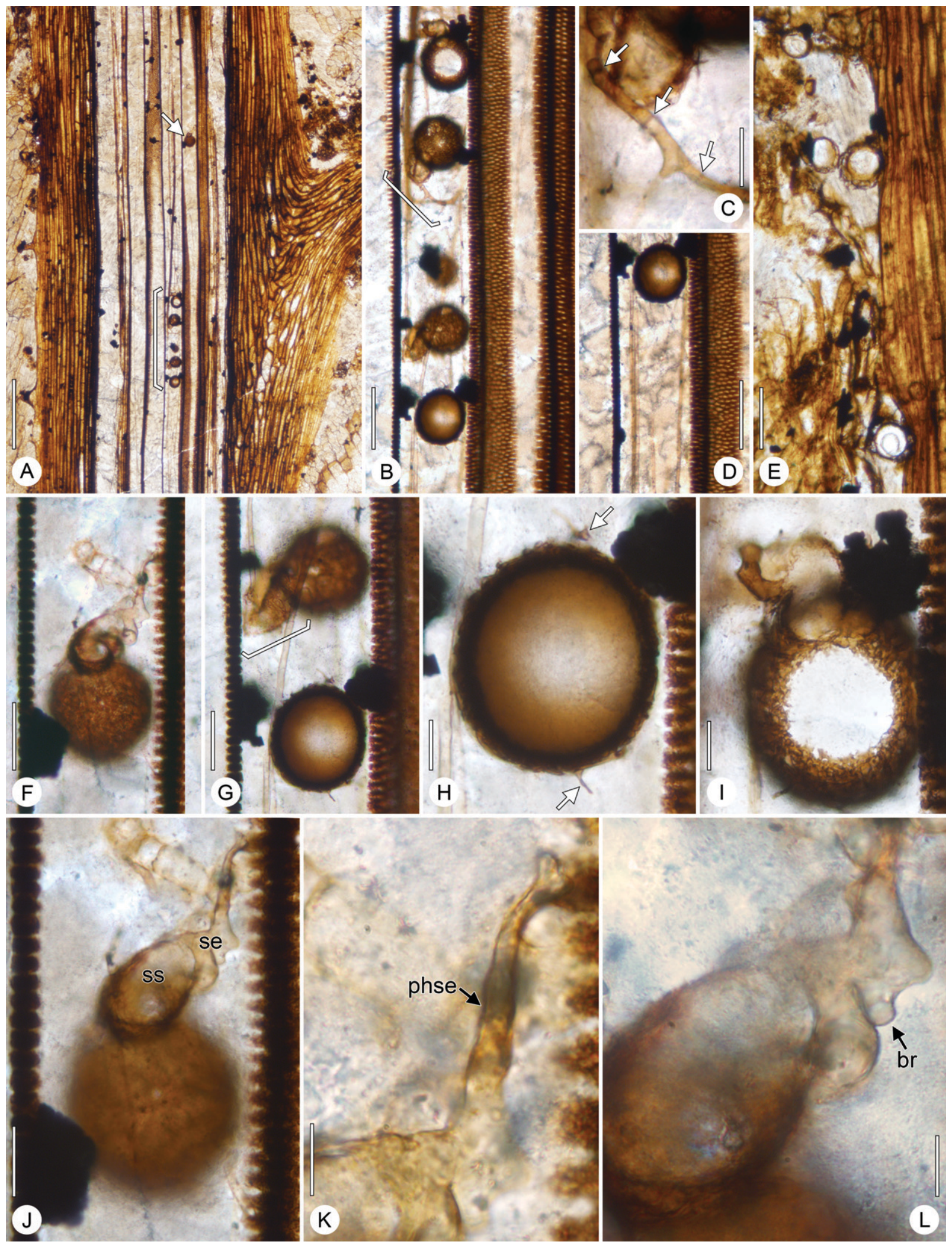

Fig. 1 Halifaxia taylorii nov. gen. et spec. from the Lower Pennsylvanian of Great Britain. All images from slide 1929, Williamson collection, Natural History Museum London, Great Britain. A, Fern axis in longitudinal section containing hyphae and reproductive units (bracketed area and arrow); bracketed area magnified in $B . B$, Reproductive units in linear arrangement; bracketed area magnified in $C$. $C$, Branch hypha with septa (arrows). D, Reproductive unit and tubular running hyphae. E, Mantled reproductive units on outer axis surface. $F$, Holotype specimen: 
tant representatives of the Glomeromycota (INVAM 2012) as well as around the zygosporangia of certain zygomycetous fungi (Bucholtz 1912; Linnemann 1941). Moreover, the cleistothecium walls in certain Ascomycota (see Gäumann 1926) may also be somewhat similar structurally to the hyphal investment of $H$. taylorii. On the other hand, prominent and persistent paired associated structures such as those of $H$. taylorii are not known in Glomeromycota or in ascomycete cleistothecia.

We therefore interpret $H$. taylorii as a sexual reproductive structure (i.e., a zygosporangium-gametangia complex) of a zygomycetous fungus. In this scenario, the sphere represents a zygosporangium enveloped in a hyphal mantle. The origin of the mantle hyphae cannot be determined. One possibility is that mantle formation initiated from the perpendicularly oriented branch hyphae, because these hyphae produce narrower second-order branches (fig. 1C) that are similar in size to the hyphae extending from the mantle into the surrounding matrix (fig. 1H). The inflated, elongate/conical structure subtending the zygosporangium accordingly represents a large gametangium (macrogametangium), or the macrogametangium and large suspensor (macrosuspensor), while the tip region of the stout branch produced by the smaller element would represent a small gametangium (microgametangium). As to whether the organism was homothallic or heterothallic cannot be determined. Moreover, the microgametangium is clearly recognizable as a distinctive compartment separated from its parental structure by a septum (fig. $2 B$ ), while a septum demarcating the macrogametangium has not been observed. It is possible that this septum simply is not preserved. On the other hand, perhaps the entire subtending structure of $H$. taylorii represents the macrogametangium, while the actual suspensor is undifferentiated or diminutive (see Benjamin 1979).

The fossil illustrated in the upper half of figure $2 B$-as well as in two different focal planes in figure $2 C$-is difficult to assess because it is quite delicate. However, if our interpretation of $H$. taylorii as a zygomycetous zygosporangiumgametangia complex is correct, then this structure might represent an early stage in zygosporangiogenesis, in which the distal spheroid represents the developing zygosporangium. Accordingly, the cylindrical element (fig. $2 B$, foreground) might equate to the microgametangial branch seen in some of the more mature specimens (fig. $2 B, 2 D$ ). If this is accurate, then the lower transverse wall (fig. $2 C_{2}$, white arrow) would represent the septum between the microgametangium and microsuspensor. The slightly inflated structure with a tapering basis (background of fig. $2 B$, white arrows) in this scenario would correspond to the subtending structure (i.e., macrogametangium, or macrogametangium and macrosuspensor) of the more mature specimens (fig. 2G). The fact that this structure is smaller than the subtending structures of the more fully developed specimens does not conflict with this interpretation, since it is known from various extant zygomycetes that the suspensors may increase considerably in size during zygosporangium development (Bucholtz 1912; Gams and Williams 1963; Kuhlman 1972; Edelmann and Klomparens 1995). It is also possible, however, that the cylindrical element represents the macrogametangium and macrosuspensor (separated by a septum; see fig. 2 $C_{2}$, white arrow), while the slightly inflated structure equates to the smaller element of the more mature specimens. The hyphae approaching the fossil structure from the surrounding matrix (fig. $2 C_{1}$, arrow) are interpreted as representing the initial stage in the formation of the mantle.

Posing a challenge to the assignment of $H$. taylorii to the zygomycetous fungi is the fact that zygosporangium and zygospore walls are not recognizable in any of the spheres interpreted as zygosporangia (fig. $2 F$ ). However, zygospores are also not recognizable in the two previously described putative zygosporangium-gametangia complexes from the British Lower Coal Measures (Krings and Taylor 2012a, 2012b), nor have they been observed in the Triassic Jimwhitea circumtecta (Krings et al. 2012). Thus, it is possible that the zygospores simply did not survive the fossilization process. As to why the zygosporangium wall is not recognizable in $H$. taylorii remains unknown. In the other putative fossil zygomycetes mentioned above, this wall is consistently well preserved. It is interesting to note, however, that the Carboniferous microfossil Mycocarpon cinctum $\mathrm{M}$ Krings et al. $(2010 b)$, an enigmatic spherical structure hypothesized to represent an isolated mantled zygosporangium, is composed of a central cavity bounded by a two-layered hyphal investment but with no evidence of an inner, nonhyphal zygosporangium wall and zygospore, precisely as in $H$. taylorii. Krings et al. (2010b) suggest that the structure may have been immature (i.e., still in the process of expansion) and the walls not yet fully developed. The cavity may have contained cytoplasm with nuclei and lipid droplets, but solid sporangium and spore walls were perhaps not deposited until the zygosporangium had reached maturity.

\section{Position of Halifaxia taylorii within the Zygomycetous Fungi}

If our interpretation of $H$. taylorii as a zygosporangiumapposed gametangia complex is correct, then the question arises as to whether the fossil can be more precisely placed within the zygomycetous fungi on the basis of the morphological features available. Zygosporangia entirely enveloped in a prominent investment (mantle) constructed of one to several layers of interlaced hyphae similar to that seen in H. taylorii (fig. $2 D-2 F$ ) are known to occur in the Endo-

reproductive unit composed of mantled sphere, subtending structure, and smaller element. $G$, Tubular running hyphae and reproductive units, one with elongate subtending structure; bracketed area magnified in fig. $2 G$. H. Hyphal mantle with narrow hyphae extending into surrounding matrix (arrows). I, Mantled sphere in cross section off center; subtending structure magnified in fig. 2I. J, Holotype specimen in higher magnification, focusing on subtending structure (ss) and smaller element (se). K, Proximal (hyphal) portion of smaller element (phse). L, Distal (irregularly lobed and branched) portion of smaller element; br = branch. Scale bars $=500 \mu \mathrm{m}(A), 100 \mu \mathrm{m}(B, D, E), 20 \mu \mathrm{m}(C, H, I), 50 \mu \mathrm{m}$ $(F, G), 30 \mu \mathrm{m}(J), 10 \mu \mathrm{m}(K, L)$. 

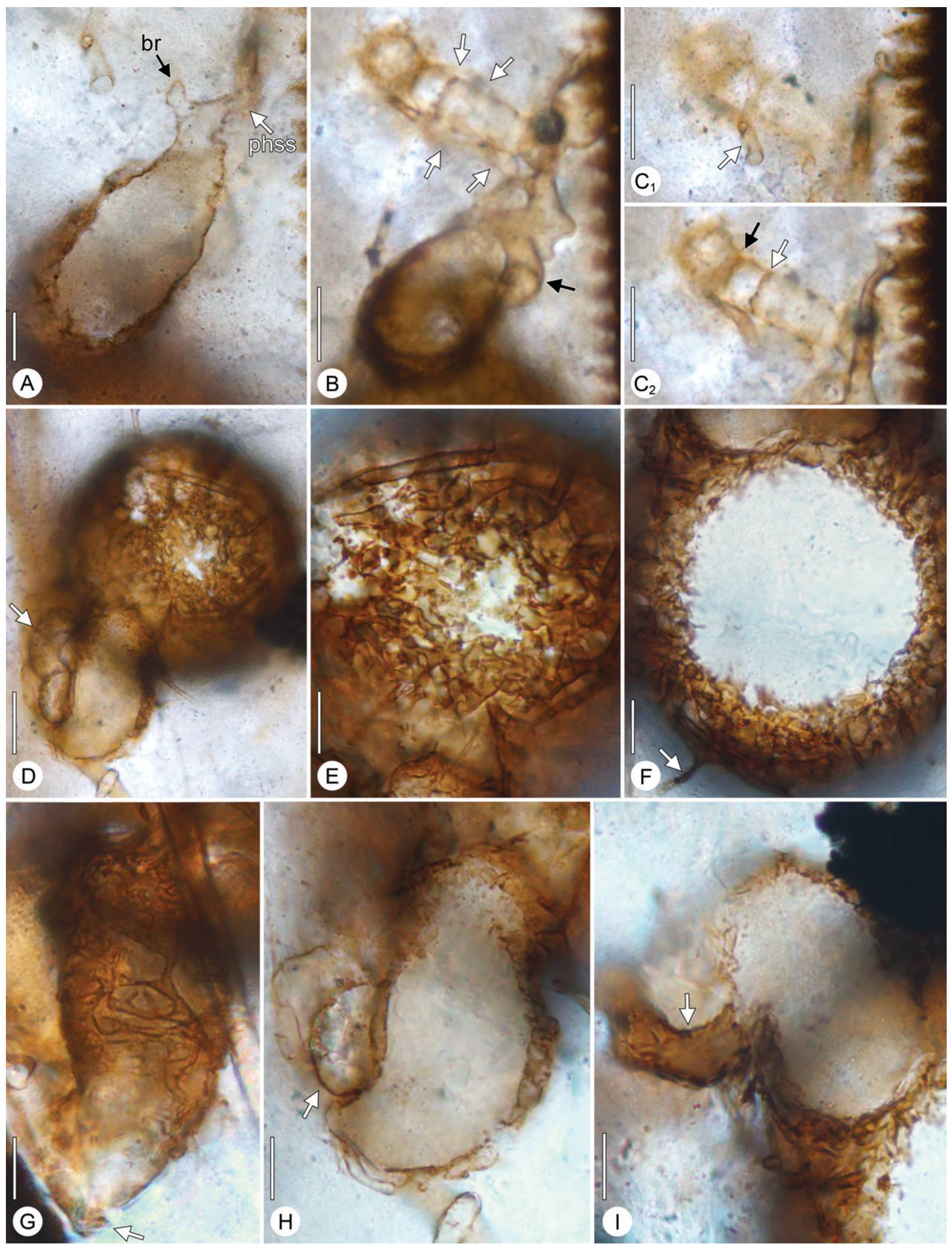

Fig. 2 Halifaxia taylorii nov. gen. et spec. from the Lower Pennsylvanian of Great Britain. All images from slide 1929, Williamson collection, Natural History Museum London, Great Britain. A, Holotype specimen, focal plane on proximal half of subtending structure and its parental hypha (phss); br = branch. B, Same as in A, different focal plane. Bottom, subtending structure in surface view and microgametangial branch (septum indicated by black arrow) arising from smaller element. Top, putative immature reproductive unit; arrows indicate slightly inflated 
gonaceae (Bucholtz 1912; Trappe and Gerdemann 1972; Błaszkowski et al. 1998). Moreover, in certain members of the Endogonaceae (especially in Endogone), the zygosporangium does not develop in the fusion area between the two gametangia but rather buds from one, usually the larger, of the apposed gametangia, which is subtended by a large suspensor. The large gametangium (macrogametangium), separated from its suspensor (macrosuspensor) by a septum, is fused laterally with a smaller microgametangium, which is separated from its suspensor (microsuspensor) by a septum (Bucholtz 1912; Thaxter 1922). If the configuration exhibited by $H$. taylorii in fact corresponds to that seen in Endogone, then the subtending structure in the fossil represents a very large macrogametangium, or the macrogametangium plus the macrosuspensor (with the septum between the two structures not preserved or not recognizable). Arguing against affinities of $H$. taylorii with the Endogonaceae is perhaps the fact that the majority of extant Endogonaceae produce zygosporangia clustered in unstructured masses or in structured sporocarps (Yao et al. 1996). There is, however, one genus in the Endogonaceae-that is, Peridiospora CG Wu et Suh J Lin-for which the production of unisporic zygosporocarps is characteristic (Wu and Lin 1997). These zygosporocarps are similar in size and overall morphology to the reproductive units of $H$. taylorii. Moreover, the apposed gametangia of Peridiospora are sheathed (at least in part) by a meshwork of interwoven hyphae, precisely as the subtending structure in some of the $H$. taylorii reproductive units (cf. fig. 2 in Wu and Lin 1997 and fig. 2G).

A structural feature of $H$. taylorii that we are not aware of occurring in Endogonaceae is the smaller element subtending the microgametangial branch and clasping around the proximal portion of the subtending structure in one of the specimens (fig. $1 \mathrm{~L}$ ). It is interesting to note, however, that a somewhat similar feature has been reported to occur during sexual reproduction in a member of the genus Mortierella Coem. (subphylum Mortierellomycotina; see Hoffmann et al. 2011). Zygosporangia in Mortierella are either naked or variously sheathed by hyphal coverings arising from the suspensors or initiated from hyphae at the base of the suspensors (Brefeld 1881; Kuhlman 1972; Chien et al. 1974; Ansell and Young 1983). Most species produce zygosporangia in the fusion area between opposed or apposed gametangia (Linnemann 1941; Zycha et al. 1969; Kuhlman 1972), but in one heterothallic species, Mortierella capitata Marchal, the microprogametangium initially develops a branched structure that entwines densely around the elongating, club-shaped macroprogametangium (Degawa and Tokumaso 1997). The entwining of the macroprogametangium by the branched microprogametangium in M. capitata is reminiscent of the embracing of the subtending structure by the smaller element in $H$. taylorii. Alternatively, the smaller element in H. taylorii might also be comparable to the progametangial coils found in numerous modern zygomycetous fungi of different systematic affinities (see Zycha et al. 1969), for example, Blakeslea trispora Thaxt. (Cutter 1942, figs. 37, 38), Phycomyces nitens (C Agardh) Kunze (Benjamin and Hesseltine 1959, fig. 4), and Syncephalis nodosa Tiegh. (Möller 1901, pl. I, fig. 18). As a result, we feel that the fossils cannot be unequivocally linked with any extant lineage within the zygomycetous fungi. We therefore have refrained from including the fossils in any of the existing subphyla but rather have left the ranks of subphylum and below unresolved.

\section{Conclusions}

Although the occurrence of fossils of zygomycetous fungi in great numbers in the coal beds of the Carboniferous had been postulated already $100 \mathrm{yr}$ ago by the British paleontologist RC McLean (1912), apart from Halifaxia taylorii described in this article, only three putative Carboniferous representatives of this group of fungi have been documented to date (Taylor et al. 2005; Krings and Taylor 2012a, $2012 b$ ). All records are based on structures interpreted as zygosporangium-gametangia complexes; none provide evidence of any other stages of the life history of these organisms. All Carboniferous zygomycetes described to date occur within the confines of plant parts such as ovules and degraded wood. This is unusual since most modern zygomycetes produce zygospores aerially, on or in the soil, or on organic debris (Benny et al. 2001). As to whether the occurrence of the Carboniferous zygosporangium-gametangia complexes within plant parts represents a preservation bias, in which only those specimens protected by plant tissue are preserved in a recognizable form, or reflects some life-history strategy of zygomycetous fungi in the Carboniferous cannot be determined. We anticipate that more complete specimens of $H$. taylorii and the other, previously described Carboniferous putative zygomycetes as well as new forms will be discovered as work on the fungi preserved in coal balls and other matrices conducive to the preservation of microorganisms (e.g., chert) continues. This will hopefully lead to a more accurate understanding of the organisms on which $H$. taylorii and the other putative zygomycete fossils were produced and help to more completely gather the full extent of fungal biodiversity that existed in Carboniferous terrestrial ecosystems. Moreover, it will expand our understanding of the evolutionary his-

structure in background. $C_{1}, C_{2}$, Immature reproductive unit in different focal planes; arrow in $C_{1}$ indicates hypha approaching structure from outside; arrows in $C_{2}$ indicate transverse lines in cylindrical element. $D$, Mantled sphere with subtending structure and microgametangial branch; arrow indicates septum. E, Hyphal mantle with tubular hyphae extending along circumference. $F$, Detail of fig. $1 H$ : inner mantle layer; arrow indicates hypha extending from mantle. $G$, Interwoven hyphae on subtending structure; arrow indicates what appears to be attachment point of subtending structure to parental hypha. $H$, Detail of $D$ (different focal plane), subtending structure and microgametangial branch (arrow) in oblique longitudinal section; note hyphal investment of subtending structure. I, Subtending structure in oblique cross section, with microgametangial branch entering from side (arrow). Scale bars $=10 \mu \mathrm{m}(A, E-I), 20 \mu \mathrm{m}(B-D)$. 
tory of zygomycetous fungi, which to date are greatly underrepresented in fossils.

\section{Acknowledgments}

This article is dedicated to Thomas N. Taylor on the occasion of his seventy-fifth birthday. We join the paleobotanical community in saluting Tom's distinguished career. He has always been a trusted friend, respected colleague, and enthusiastic teacher in the study of fossil plants and fungi.
Financial support was received from the National Science Foundation (EAR-0949947 to M. Krings) and the Alexander von Humboldt-Foundation (V-3.FLF-DEU/1064359 to M. Krings). We wish to extend our sincere appreciation to Paul Kenrick, Lil Stevens, and Timothy A. M. Ewin (London) for making the slide from the Williamson collection available and for their support of this project. The article greatly benefited from the constructive comments and suggestions of Mihai Tomescu and an anonymous reviewer.

\section{Literature Cited}

Ansell PJ, TWK Young 1983 Light and electron microscopy of Mortierella indohii zygospores. Mycologia 75:64-69.

Batra LR, H Segal, RW Baxter 1964 A new Middle Pennsylvanian fossil fungus. Am J Bot 51:991-995.

Baxter RW 1975 Fossil fungi from American Pennsylvanian coal balls. Univ Kans Paleontol Contrib 77:1-6.

Benjamin CR, CW Hesseltine 1959 Studies on the genus Phycomyces. Mycologia 51:751-771.

Benjamin RK 1979 Zygomycetes and their spores. Pages 573-621 in B Kendrick, ed. The whole fungus. II. The sexual-asexual synthesis. National Museum of Natural Sciences, National Museums of Canada, and Kananaskis Foundation, Ottawa, Canada.

Benny GL, RA Hamber, JB Morton 2001 Zygomycota: Zygomycetes. Pages 113-146 in DJ McLoughlin, EG McLoughlin, PA Lemke, eds. The Mycota. VIIA. Systematics and Evolution. Springer, Berlin.

Berbee LM, JW Taylor 2001 Fungal molecular evolution: gene trees and geologic time. Pages 229-245 in DJ McLaughlin, EG McLaughlin, PA Lemke, eds. The Mycota. VIIB. Systematics and evolution. Springer, Berlin.

Blair JE 2009 Fungi. Pages 215-219 in SB Hedges, S Kumar, eds. The timetree of life. Oxford University Press, New York.

Błaszkowski J, M Tadych, T Madej 1998 Endogone maritima, a new species in the Endogonales from Poland. Mycol Res 102:10961100.

Brefeld O 1881 Botanische Untersuchungen über Schimmelpilze. Untersuchungen aus dem Gesammtgebiete der Mykologie, IV. Heft. Verlag von Arthur Felix, Leipzig.

Bucholtz F 1912 Beiträge zur Kenntnis der Gattung Endogone Link. Beih Bot Centralbl 29:147-224.

Cash W, T Hick 1879 On fossil fungi from the Lower Coal-Measures of Halifax. Proc Yorkshire Geol Polytech Soc 7:115-121.

Chien CY, EG Kuhlman, W Gams 1974 Zygospores in two Mortierella species with "stylospores." Mycologia 66:114-121.

Cutter VM Jr 1942 Behavior in the Mucorales. I. The Mucor pattern. Bull Torrey Bot Club 69:480-508.

Degawa Y, S Tokumasu 1997 Zygospore formation in Mortierella capitata. Mycoscience 38:387-394.

Edelmann RE, KL Klomparens 1995 Zygosporogenesis in Zygorbynchus heterogamus, with proposal for standardization of structural nomenclature. Mycologia 87:304-318.

Fassi B, A Fontana, JM Trappe 1969 Ectomycorrhizae formed by Endogone lactiflua with species of Pinus and Pseudotsuga. Mycologia 61:412-414.

Galtier J 1997 Coal-ball floras of the Namurian-Westphalian of Europe. Rev Palaeobot Palynol 95:51-72.

Gams W, ST Williams 1963 Heterothallism in Mortierella parvispora Linnemann. Nova Hedwigia Beih 5:347-357.

Gäumann E 1926 Vergleichende Morphologie der Pilze. Verlag von Gustav Fischer, Jena.
Heckman DS, DM Geiser, BR Eidell, RL Stauffer, NL Kardos, SB Hedges 2001 Molecular evidence for the early colonization of land by fungi and plants. Science 293:1129-1133.

Hoffmann K, K Voigt, PM Kirk 2011 Mortierellomycotina subphyl. nov., based on multi-gene genealogies. Mycotaxon 115:353-363.

INVAM 2012 International culture collection of (vesicular) arbuscular mycorrhizal fungi. West Virginia University, Morgantown. http://invam.caf.wvu.edu.

Krings M, N Dotzler, TN Taylor, J Galtier 2010a A fungal community in plant tissue from the Lower Coal Measures (Langsettian, Lower Pennsylvanian) of Great Britain. Bull Geosci 85:679-690.

$2010 b$ Microfungi from the upper Visean (Mississippian) of central France: structure and development of the sporocarp Mycocarpon cinctum nov. sp. Zitteliana A 50:127-135.

Krings M, TN Taylor 2012a Fungal reproductive units enveloped in a hyphal mantle from the Lower Pennsylvanian of Great Britain, and their relevance to our understanding of Carboniferous fungal "sporocarps." Rev Palaeobot Palynol 175:1-9.

$2012 b$ Microfossils with possible affinities to the zygomycetous fungi in a Carboniferous cordaitalean ovule. Zitteliana A 52: 3-7.

Krings M, TN Taylor, N Dotzler, G Persichini 2012 Fossil fungi with suggested affinities to the Endogonaceae from the Middle Triassic of Antarctica. Mycologia 104:835-844.

Krings M, TN Taylor, EL Taylor, N Dotzler, C Walker 2011 a Arbuscular mycorrhizal-like fungi in Carboniferous arborescent lycopsids. New Phytol 191:311-314.

Krings M, TN Taylor, JF White Jr $2011 b$ Fungal sporocarps from the Carboniferous: an unusual specimen of Traquairia. Rev Palaeobot Palynol 168:1-6.

Kuhlman EG 1972 Variation in zygospore formation among species of Mortierella. Mycologia 64:325-341.

Linnemann G 1941 Die Mucorineen-Gattung Mortierella Coemans. Pflanzenforschung 23:1-64.

Liu XY, K Voigt 2010 Molecular characters of the zygomycetous fungi. Pages 461-488 in Y Gherbawy, K Voigt, eds. Molecular identification of fungi. Springer, Berlin.

Liu Y, ET Steenkamp, H Brinkmann, L Forget, H Philippe, BF Lang 2009 Phylogenomic analyses predict sistergroup relationship of nucleariids and Fungi and paraphyly of zygomycetes with significant support. BMC Evol Biol 9:272.

McLean RC 1912 A group of rhizopods from the Carboniferous period. Proc Camb Philos Soc 16:493-513.

Möller A 1901 Phycomyceten und Ascomyceten. Untersuchungen aus Brasilien. Botanische Mittheilungen aus den Tropen, Heft 9. Verlag von Gustav Fischer, Jena.

Richardson M 2009 The ecology of the Zygomycetes and its impact on environmental exposure. Clin Microbiol Infect 15(suppl):2-9.

Strullu-Derrien C, P Kenrick, JP Rioult, DG Strullu 2011 Evidence of 
parasitic Oomycetes (Peronosporomycetes) infecting the stem cortex of the Carboniferous seed fern Lyginopteris oldhamia. Proc R Soc B 278:675-680.

Taylor TN, M Krings, SD Klavins, EL Taylor 2005 Protoascon missouriensis, a complex fossil microfungus revisited. Mycologia 97:725-729.

Thaxter R 1922 A revision of the Endogoneae. Proc Am Acad Art Sci 57:291-351.

Trappe JM, JW Gerdemann 1972 Endogone flammicorona sp. nov., a distinctive segregate from Endogone lactiflua. Trans Br Mycol Soc 59:403-407.

Walker C 1985 Endogone lactiflua forming ectomycorrhizas with Pinus contorta. Trans Br Mycol Soc 84:353-355.

White JF, TN Taylor 1989 Triassic fungi with suggested affinities to the Endogonales (Zygomycotina). Rev Palaeobot Palynol 61:53-61.

1991 Fungal sporocarps from Triassic peat deposits in Antarctica. Rev Palaeobot Palynol 67:229-236.

White MM, TJ James, K O’Donnell, MJ Cafaro, Y Tanabe,
J Sugiyama 2006 Phylogeny of the Zygomycota based on nuclear ribosomal sequence data. Mycologia 98:872-884.

Williamson WC 1880 On the organization of the fossil plants of the Coal-Measures. X. Including an examination of the supposed radiolarians of the carboniferous rocks. Philos Trans R Soc B 171: 493-539.

1881 On the organization of fossil plants of the Coal Measures. XI. Philos Trans R Soc B 172:283-305.

1883 On the organization of the fossil plants of the CoalMeasures. XII. Philos Trans R Soc B 174:459-475.

Wu CG, SJ Lin 1997 Endogonales in Taiwan: a new genus with unizygosporic sporocarps and a hyphal mantle. Mycotaxon 64: 179-188.

Yao YJ, DN Pegler, TWK Young 1996 Genera of Endogonales. Royal Botanic Gardens, Surrey.

Zycha H, R Siepmann, G Linnemann 1969 Mucorales. Eine Beschreibung aller Gattungen und Arten dieser Pilzgruppe. Verlag von J Cramer, Lehre. 